\title{
Outcomes of Dyslipidemia Screening Program in School-aged Children
}

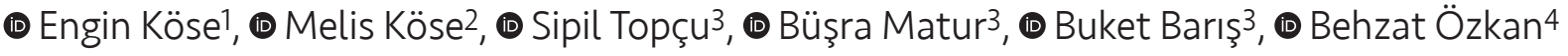 \\ ${ }^{1}$ Ankara University Faculty of Medicine, Department of Pediatric Metabolism and Nutrition, Ankara, Turkey \\ 2izmir Katip Çelebi 3University Faculty of Medicine, Department of Pediatric Metabolism and Nutrition, İzmir, Turkey \\ 3University of Health Sciences Turkey, Dr. Behçet Uz Children Training and Research Hospital, Clinic of Pediatrics, İzmir, Turkey \\ 4University of Health Sciences Turkey, Dr. Behçet Uz Children Training and Research Hospital, Clinic of Pediatric Endocrinology, İzmir, Turkey
}

\begin{abstract}
Aim: Screening of dyslipidemia in childhood has been controversial. While some guidelines recommend screening for dyslipidemia in children, others emphasize that there is insufficient evidence for screening for dyslipidemia in those less than 20 years of age. In this study, we aimed to evaluate the outcomes of a lipid screening program and reveal the pros and cons of this program.

Materials and Methods: All patients referred to a paediatric metabolism outpatient clinic by family physicians with the suspicion of dyslipidemia in a lipid screening program at schools were investigated. Demographic and physical examination findings, screening lipid profiles and fasting control lipid profiles of the patients were evaluated. The definitive diagnosis with fasting lipid profile and genetic analysis were recorded.

Results: Two hundred seventy-four patients suspected with dyslipidemia were enrolled in the study. The mean age of study group was $9.2 \pm 3.2$ (5-17) years. While 158 (57.7\%) patients were admitted with high total cholesterol (TC) and low-density lipoprotein cholesterol, high triglyceride level was detected in 58 (21.2\%) patients via a paediatric lipid screening program. A high TC level was revealed in 26 (9.5\%) patients.

With the control fasting lipid profile, 100 (36.5\%) patients had a normal lipid profile. Fifty-nine (21.5\%) patients were diagnosed with familial hypercholesterolemia (FH), and hyperchylomicronemia and hypobetalipoproteinemia were revealed in $5(1.8 \%)$ and $4(1.5 \%)$ patients, respectively. Eleven patients diagnosed with FH did not declare hyperlipidemia in parents. In a screening of these patients' immediate families, 11 parents and 3 siblings were diagnosed with familial hyperlipidemia.

Conclusion: This is the first study performed to date that evaluated the outcomes of a lipid screening program on school age children in Turkey. We found that this screening program is effective in diagnosing not only the patients but also asymptomatic parents and siblings. Evaluation and verification of dyslipidemia should be performed under fasting conditions to avoid false positive results.
\end{abstract}

Keywords: Screening of dyslipidemia, school-aged children, familial hypercholesterolemia

\section{Introduction}

It is well known that elevated total cholesterol (TC), especially low-density lipoprotein cholesterol (LDL-C), is the major preventable risk factor for atherosclerotic cardiovascular disease, which is the most common cause of death in developed countries. Early diagnosis of dyslipidemia and the initiation of lipid-lowering treatment is important to avoid atherosclerotic effects (1).

Screening for dyslipidemia in childhood has been controversial. While some guidelines recommend screening 
of dyslipidemia in children, the US Preventive Services Task Force emphasizes that there is insufficient evidence for the screening for dyslipidemia in those under 20 years of age $(2,3)$. On the other hand, some authors recommend targeted screening based on a family history of premature cardiovascular disease or hypercholesterolemia or other risk factors (4). However, it has been pointed out that such an approach would miss a large number of children with dyslipidemia (5). No doubt, there is a need for clinical research to reach a consensus on this issue.

In the presence of such uncertainties, a dyslipidemia screening program in school-age children was initiated in Turkey in 2016 (6). The aim of this screening program was the evaluation of all school-aged children in terms of an abnormal lipid profile. Children with abnormal lipid profiles [TC $\geq 200 \mathrm{mg} / \mathrm{dL}$, LDL-C $\geq 130 \mathrm{mg} / \mathrm{dL}$, triglyceride $\geq 100 \mathrm{mg} /$ $\mathrm{dL}$ for $5-9$ years of age and $\geq 130 \mathrm{mg} / \mathrm{dL}$ for $10-18$ years of age and high-density lipoprotein cholesterol (HDL-C) $<40$ $\mathrm{mg} / \mathrm{dL}]$ are referred to paediatric metabolism outpatient clinics to be evaluated for dyslipidemia. To date, no study has analysed the efficacy and outcomes of this screening program in Turkey. In this study, we aimed to evaluate the outcomes and reveal the pros and cons of this lipid screening program.

\section{Materials and Methods}

Patients referred to paediatric metabolism outpatient clinics by family physicians with suspected dyslipidemia (TC $\geq 200 \mathrm{mg} / \mathrm{dL}, \mathrm{LDL}-\mathrm{C} \geq 130 \mathrm{mg} / \mathrm{dL}$, triglyceride $\geq 100 \mathrm{mg} / \mathrm{dL}$ for $5-9$ years of age and $\geq 130 \mathrm{mg} / \mathrm{dL}$ for $10-18$ years of age and $\mathrm{HDL}-\mathrm{C}<40 \mathrm{mg} / \mathrm{dL}$ ) during the lipid screening program at schools were investigated between July 2018 and October 2019.

Patients with results obtained during the screening program and a control fasting lipid profile (after fasting for at least 9 hours) were enrolled. Their demographics and physical examination findings [age, gender, family history of dyslipidemia, lipid-lowering treatment or premature symptomatic coronary artery disease, body mass index (BMI)], screening lipid profile (TC, LDL-C, triglycerides, HDLC) and fasting control lipid profile were evaluated. Definitive diagnoses with fasting lipid profile and genetic analysis (LDLR, APOB, LDLRAP1, PCSK9, APOC2, LPL, and MTP) [normal lipid profile, familial hypercholesterolemia (FH), hypobetalipoproteinemia, hyperchylomicronemia, nonclassified high total and LDL-cholesterol] were recorded. A $\mathrm{BMI} \geq 95^{\text {th }}$ percentile was defined as obesity (7). The cut-off points for TC and LDL-C were $\geq 200 \mathrm{mg} / \mathrm{dL}$ and $\geq 130 \mathrm{mg} /$ $\mathrm{dL}$, respectively. Furthermore, $\geq 100 \mathrm{mg} / \mathrm{dL}$ for $5-9$ years of age and $\geq 130 \mathrm{mg} / \mathrm{dL}$ for $10-18$ years of age were determined as the cut-off points of triglyceride level (8). Children with LDL cholesterol $\geq 190 \mathrm{mg} / \mathrm{dL}$ or LDL cholesterol $\geq 160 \mathrm{mg} /$ $\mathrm{dL}$ with risk factors were evaluated for genetic mutation for $\mathrm{FH}$. Also, children with LDL cholesterol $\geq 130 \mathrm{mg} / \mathrm{dL}$ with $\mathrm{FH}$ diagnosed parents were assessed with genetic analysis. All patients with high triglycerides levels $(\geq 500 \mathrm{mg} / \mathrm{dL}$ and/ or persistent triglyceride levels between $130-500 \mathrm{mg} / \mathrm{dL}$ without obesity) were investigated with genetic analysis for hyperchylomicronemia. In patients with LDL cholesterol $\leq 50 \mathrm{mg} / \mathrm{dL}$, hypobetalipoproteinemia was genetically investigated (9). The lipid prolife of the parents and siblings of patients diagnosed with $\mathrm{FH}$, hypobetalipoproteinemia or hyperchylomicronemia were investigated. Twelve patients were excluded from the study due to missing data. Informed assent from the participants (whenever appropriate) and written informed consent from their caregivers were obtained.

The study was initiated after the approval of the Ethics Committee of University of Health Sciences Turkey, Dr. Behçet Uz Children Training and Research Hospital (date: 12.09.2019, number: 2019/326).

\section{Statistical Analysis}

Categorical variables (gender, family history of hyperlipidemia, lipid-lowering treatment and premature coronary artery disease) were expressed as number and percentage, and continuous variables (age, TC, LDL-C, triglycerides and HDL-C in the screening program and the fasting control lipid profile) were expressed as mean \pm standard deviation or median (min-max) according to the normality of variables. The normality of data was assessed with Kolmogorov-Smirnov and Shapiro-Wilk tests. Comparison of the frequency of hyperlipidemia and lipidlowering treatment in family history across subgroups was analysed with chi-square test.

Data were analysed with the Statistical Package for Social Sciences (SPSS) computer software (version 21.0; SPSS, Chicago, IL, USA). A two-tailed $p$-value $<0.05$ was considered significant.

\section{Results}

Two hundred and seventy-four patients with suspected dyslipidemia were enrolled in the study. Of these, 145 $(52.9 \%)$ were female and $129(47.1 \%)$ were male. The mean age of the study group was $9.2 \pm 3.2$ (5-17) years. In the family history, hyperlipidemia in parents was declared by 116 (42.3\%) patients and 35 (12.8\%) (father or mother) were receiving lipid-lowering treatment. Premature symptomatic 
coronary artery disease was detected in $4(1.5 \%)$ parents. Physical examination revealed obesity in 42 (15.3\%) patients.

In physical examination, one of the patients diagnosed with familial hyperlipidemia had xanthoma in the knees. None of the children had ocular manifestations (corneal arcus, lipemia retinalis). Two out of 4 patients diagnosed with hypobetalipoproteinemia had mild hepatomegaly. Two patients with hypobetalipoproteinemia were asymptomatic.

The lipid profiles of the patients during screening are presented in Table I. While 158 (57.7\%) patients were admitted with elevated TC ( $\geq 200 \mathrm{mg} / \mathrm{dL})$ and LDL-C ( $\geq 130$ $\mathrm{mg} / \mathrm{dL}$ ), elevated triglycerides ( $5-9$ years of age: $\geq 100 \mathrm{mg} / \mathrm{dL}$, $10-17$ years of age: $\geq 130 \mathrm{mg} / \mathrm{dL}$ ) was detected in $58(21.2 \%)$ patients by the paediatric lipid screening program. High TC level was noted in 26 (9.5\%) patients.

In the assessment of patients via the control fasting lipid profile, 100 (36.5\%) patients had a normal lipid profile. While $59(21.5 \%)$ patients were diagnosed with $\mathrm{FH}$, (patients with genetic mutation in $L D L R, P(S K 9)$, hyperchylomicronemia and hypobetalipoproteinemia were found in $5(1.8 \%)$ and 4 (1.5\%) patients, respectively. High TC and LDL-C without genetic mutations in $\angle D L R$, APOB, LDLRAP1, PCSK9, APOC2, $L P L$, and MTP was detected in $64(23.4 \%)$ patients. The control fasting lipid profiles of the groups are presented in Table II.

Comparison of the lipid profile obtained during the screening program and the diagnosis of patients revealed that all patients admitted with a high TC level had a normal fasting lipid profile. Also, a normal fasting lipid profile was determined in $38(65.5 \%)$ out of the 58 patients with elevated triglycerides. FH was diagnosed in 59 (37\%) patients with high TC and high LDL-C. All patients $(n=4)$ with low TC, low LDL-C and low triglyceride levels were diagnosed with hypobetalipoproteinemia (Table III).

In the evaluation of the family history of the patients, hyperlipidemia and receiving lipid-lowering treatment in parents were more frequent in patients with $\mathrm{FH}$ compared to the other groups $(p<0.0001 ; p<0.0001)$ (Table IV). Eleven patients diagnosed with $\mathrm{FH}$ did not declare hyperlipidemia in their parents. An evaluation of the fasting lipid profile of these patients' families with cascade screening revealed that 11 parents $(2.0 \%$ of the parents of patients enrolled in the study) and 3 siblings had familial hyperlipidemia. The mean TC and LDL-C levels of the parents were $297.4 \pm 76.3$ (256$398) \mathrm{mg} / \mathrm{dL}$ and $234.0 \pm 64.1(180-310) \mathrm{mg} / \mathrm{dL}$, respectively.

\section{Discussion}

This is the first study performed to date to evaluate the outcomes of a dyslipidemia screening program in schoolage children in Turkey. The most striking point of this study is that one third of the patients referred with suspected dyslipidemia had a normal fasting lipid profile. This finding may be explained by the fact that the lipid screening was conducted in a non-fasting state $(10,11)$. It is well known that triglyceride level is affected by the fasting state. Consequently, most of our patients with normal lipid profiles were admitted with high triglyceride levels.

Another interesting point is those patients referred with elevated TC, all of whom had normal control fasting lipid profiles. Most studies indicate that the fasting or nonfasting state of patients does not affect TC and LD-C levels, advising that lipid screening be performed in a non-fasting state $(12,13)$. However, a study recently performed in Turkey indicated that a fasting state may affect TC and non-HDL-C

Table I. Total cholesterol, LDL-cholesterol, HDL-cholesterol and triglyceride levels of patients in the screening program

\begin{tabular}{|l|l|l|l|l|l|l|}
\hline $\begin{array}{l}\text { Lipid profile in screening } \\
(\mathbf{m g} / \mathbf{d L})\end{array}$ & $\begin{array}{l}\text { Group 1 } \\
\mathbf{( n = 2 6 )}\end{array}$ & $\begin{array}{l}\text { Group 2 } \\
\mathbf{( n = 5 8 )}\end{array}$ & $\begin{array}{l}\text { Group 3 } \\
\mathbf{( n = 1 5 8 )}\end{array}$ & $\begin{array}{l}\text { Group 4 } \\
\mathbf{( n = 1 4 )}\end{array}$ & $\begin{array}{l}\text { Group 5 } \\
(\mathbf{n = 1 4 )}\end{array}$ & $\begin{array}{l}\text { Group 6 } \\
\mathbf{( n = 4 )}\end{array}$ \\
\hline TC, mean \pm SD (min-max) & $\begin{array}{l}204.0 \pm 4.2 \\
(200-214)\end{array}$ & $\begin{array}{l}164.7 \pm 24.1 \\
(87-199)\end{array}$ & $\begin{array}{l}260.1 \pm 68.6 \\
(200-834)\end{array}$ & $\begin{array}{l}231.6 \pm 24.6 \\
(201-298)\end{array}$ & $\begin{array}{l}212.2 \pm 9.4 \\
(200-230)\end{array}$ & $\begin{array}{l}51.8 \pm 14.9 \\
(32-68)\end{array}$ \\
\hline LDL-C, mean \pm SD (min-max) & $\begin{array}{l}113.3 \pm 11.6 \\
(86-128)\end{array}$ & $\begin{array}{l}82.9 \pm 21.3 \\
(32-127)\end{array}$ & $\begin{array}{l}183.2 \pm 68.7 \\
(130-752)\end{array}$ & $\begin{array}{l}146.6 \pm 22.1 \\
(131-219)\end{array}$ & $\begin{array}{l}106.2 \pm 10.6 \\
(89-125)\end{array}$ & $\begin{array}{l}21.8 \pm 8.8 \\
(11-32)\end{array}$ \\
\hline HDL-C, mean \pm SD (min-max) & $\begin{array}{l}64.3 \pm 12.8 \\
(42-94)\end{array}$ & $\begin{array}{l}38.9 \pm 14.1 \\
(12-81)\end{array}$ & $\begin{array}{l}59.2 \pm 13.4 \\
(33-100)\end{array}$ & $\begin{array}{l}47.3 \pm 6.9 \\
(39-52)\end{array}$ & $\begin{array}{l}58.5 \pm 17.6 \\
(30-80)\end{array}$ & $\begin{array}{l}35.3 \pm 2.6 \\
(28-39)\end{array}$ \\
\hline Triglycerides, median (min-max) & $\begin{array}{l}81 \\
(39-126)\end{array}$ & $\begin{array}{l}260 \\
(145-1,939)\end{array}$ & $\begin{array}{l}78 \\
(41-127)\end{array}$ & $\begin{array}{l}192 \\
(142-312)\end{array}$ & $\begin{array}{l}222 \\
(110-343)\end{array}$ & $\begin{array}{l}21.5 \\
(19-35)\end{array}$ \\
\hline
\end{tabular}

Group 1: High TC

Group 2: High triglycerides

Group 3: High TC, high LDL-C

Group 4: High TC, high LDL-C, high triglycerides

Group 5: High TC, high triglycerides

Group 6: Low TC, low LDL-C, low triglycerides

LDL-C: Low-density lipoprotein cholesterol, min: Minimum, max: Maximum, SD: Standard deviation, TC: Total cholesterol 
Table II. Control fasting lipid profiles and diagnoses of patients

\begin{tabular}{|l|l|l|l|l|l|l|}
\hline $\begin{array}{l}\text { Control fasting } \\
\text { lipid profile } \\
\text { (mg/dL) }\end{array}$ & $\begin{array}{l}\text { Normal lipid } \\
\text { profile } \\
(\mathbf{n = 1 0 0 )}\end{array}$ & $\begin{array}{l}\text { Familial } \\
\text { hypercholesterolemia } \\
\mathbf{( n = 5 9 )}\end{array}$ & $\begin{array}{l}\text { Obesity } \\
\mathbf{( n = 4 2 )}\end{array}$ & $\begin{array}{l}\text { Non-classified } \\
\text { high total } \\
\text { and LDL- } \\
\text { cholesterol } \\
\mathbf{( n = 6 4 )}\end{array}$ & $\begin{array}{l}\text { Hyperchylomicronemia } \\
\text { (n=5) }\end{array}$ & $\begin{array}{l}\text { Hypobetalipoproteinemia } \\
\text { (n=4) }\end{array}$ \\
\hline $\begin{array}{l}\text { TC, mean } \pm \text { SD } \\
\text { (min-max) }\end{array}$ & $\begin{array}{l}168.9 \pm 20.4 \\
(107-198)\end{array}$ & $\begin{array}{l}318.4 \pm 80.3 \\
(234-798)\end{array}$ & $\begin{array}{l}212.4 \pm 38.1 \\
(144-297)\end{array}$ & $\begin{array}{l}227.9 \pm 18.5 \\
(200-279)\end{array}$ & $\begin{array}{l}201.8 \pm 39.9 \\
(157-252)\end{array}$ & $\begin{array}{l}73.8 \pm 16.9 \\
(52-91)\end{array}$ \\
\hline $\begin{array}{l}\text { LDL-C, mean } \pm \text { SD } \\
\text { (min-max) }\end{array}$ & $\begin{array}{l}96.5 \pm 15.9 \\
(52-124)\end{array}$ & $\begin{array}{l}245.5 \pm 76.4 \\
(170-702)\end{array}$ & $\begin{array}{l}123.5 \pm 34.5 \\
(63-186)\end{array}$ & $\begin{array}{l}149.4 \pm 15.2 \\
(130-187)\end{array}$ & $*$ & $32.8 \pm 16.5$ \\
\hline $\begin{array}{l}\text { HDL-C, mean } \pm \text { SD } \\
\text { (min-max) }\end{array}$ & $\begin{array}{l}56.2 \pm 11.3 \\
(40-90)\end{array}$ & $\begin{array}{l}58.2 \pm 1361 \\
(30-89)\end{array}$ & $\begin{array}{l}47.9 \pm 14.1 \\
(22-81)\end{array}$ & $\begin{array}{l}59.8 \pm 12.9 \\
(36-88)\end{array}$ & $\begin{array}{l}15.8 \pm 5.7 \\
(12-24)\end{array}$ & $\begin{array}{l}43.8 \pm 1.9 \\
(41-45)\end{array}$ \\
\hline $\begin{array}{l}\text { Triglyceride, } \\
\text { median (min-max) }\end{array}$ & $\begin{array}{l}78.5 \\
(65-123)\end{array}$ & $\begin{array}{l}79 \\
(47-126)\end{array}$ & $\begin{array}{l}204 \\
(41-680)\end{array}$ & $\begin{array}{l}82.3 \\
(44-127)\end{array}$ & $\begin{array}{l}984 \\
(773-1,230)\end{array}$ & 32.5 \\
\hline $\begin{array}{l}* \\
\text { *: Could not be calculated due to high triglyceride level. } \\
\text { HDL-C: High-density lipoprotein cholesterol, LDL-C: Low-density lipoprotein cholesterol, min: Minimum, max: Maximum, SD: Standard deviation, TC: Total cholesterol }\end{array}$
\end{tabular}

Table III. Comparison of lipid profiles in screening and the diagnoses of patients

\begin{tabular}{|c|c|c|c|c|c|c|}
\hline \multirow{2}{*}{$\begin{array}{l}\text { Diagnosis of patients with control fasting lipid profile } \\
\text { and genetic investigations, }\end{array}$} & \multicolumn{6}{|c|}{ Lipid profile in screening $\mathbf{n}(\%)$} \\
\hline & $\begin{array}{l}\text { Group } 1 \\
(n=26)\end{array}$ & $\begin{array}{l}\text { Group } 2 \\
(\mathrm{n}=58)\end{array}$ & $\begin{array}{l}\text { Group } 3 \\
(n=158)\end{array}$ & $\begin{array}{l}\text { Group } 4 \\
(\mathrm{n}=14)\end{array}$ & $\begin{array}{l}\text { Group } 5 \\
(n=14)\end{array}$ & $\begin{array}{l}\text { Group } 6 \\
(n=4)\end{array}$ \\
\hline Normal lipid profile $(n=100)$ & $26(100.0)$ & $38(65.5)$ & $27(17.0)$ & $3(21.4)$ & $6(41.9)$ & $0(0.0)$ \\
\hline Familial hypercholesterolemia $(n=59)$ & $0(0.0)$ & $0(0.0)$ & $59(37.0)$ & $0(0.0)$ & $0(0.0)$ & $0(0.0)$ \\
\hline Obesity $(n=42)$ & $0(0.0)$ & $15(25.9)$ & $8(5.1)$ & $11(78.6)$ & $8(57.1)$ & $0(0.0)$ \\
\hline Non-classified high TC and LDL-C $(n=64)$ & $0(0.0)$ & $0(0.0)$ & $64(41.0)$ & $0(0.0)$ & $0(0.0)$ & $0(0.0)$ \\
\hline Hyperchylomicronemia $(n=4)$ & $0(0.0)$ & $5(8.6)$ & $0(0.0)$ & $0(0.0)$ & $0(0.0)$ & $0(0.0)$ \\
\hline Hypobetalipoproteinemia $(n=4)$ & $0(0.0)$ & $0(0.0)$ & $0(0.0)$ & $0(0.0)$ & $0(0.0)$ & $4(100.0)$ \\
\hline \multicolumn{7}{|l|}{$\begin{array}{l}\text { Group 1: High TC } \\
\text { Group2: High triglycerides } \\
\text { Group 3: High TC, high LDL-C } \\
\text { Group 4: High TC, high LDL-C, high triglycerides } \\
\text { Group 5: High TC, high triglycerides } \\
\text { Group 6: Low TC, low LDL-C, low triglycerides } \\
\text { LDL-C: Low-density lippoprotein cholesterol, TC: Total cholesterol }\end{array}$} \\
\hline
\end{tabular}

Table IV. Hyperlipidemia and lipid-lowering therapy in family history of subgroups

\begin{tabular}{|l|l|l|l|l|l|l|l|}
\hline & $\begin{array}{l}\text { Normal } \\
\text { lipid } \\
\text { history } \\
\text { profile } \\
(\mathbf{n = 1 0 0 )} \\
\mathbf{n}(\%)\end{array}$ & $\begin{array}{l}\text { Familial } \\
\text { hypercholesterolemia } \\
(\mathbf{n = 5 9 )} \mathbf{n}(\%)\end{array}$ & $\begin{array}{l}\text { Obesity } \\
\mathbf{( n = 4 2 )} \\
\mathbf{n}(\%)\end{array}$ & $\begin{array}{l}\text { Non-classified } \\
\text { high total and } \\
\text { LDL-cholesterol } \\
(\mathbf{n = 6 4 )} \mathbf{n}(\%)\end{array}$ & $\begin{array}{l}\text { Hyperchylomicronemia } \\
(\mathbf{n = 5}) \mathbf{n}(\%)\end{array}$ & $\begin{array}{l}\text { Hypobetalipoproteinemia } \\
(\mathbf{n = 4 )} \mathbf{n}(\%)\end{array}$ & $\mathbf{p}$ \\
\hline $\begin{array}{l}\text { Hyperlipidemia } \\
\text { in parents } \\
(\mathbf{n = 1 1 6 )}\end{array}$ & $26(26.0)$ & $48(81.4)$ & $12(28.6)$ & $29(45.3)$ & $1(20.0)$ & $0(0.0)$ & $<0.0001$ \\
\hline $\begin{array}{l}\text { Lipid-lowering } \\
\text { therapy in } \\
\text { parents (n=35) }\end{array}$ & $3(3.0)$ & $19(32.0)$ & $3(7.1)$ & $9(14.0)$ & $1(20.0)$ & $0(0.0)$ & $<0.0001$ \\
\hline
\end{tabular}

levels (14). It is difficult to comment on this subject within the method of our study. However, we determined that those patients admitted with elevated TC had slightly elevated $\mathrm{HDL}-\mathrm{C}$, which we believe is the reason for their high TC levels. This finding suggests that physicians should pay attention to elevated non-HDL-C instead of TC levels in lipid screening programs.

The primary aim of a lipid screening program is to determine elevated $L D L-C$, the most common and preventable factor for atherosclerotic cardiovascular 
disease, in asymptomatic patients (15). In this study, we found that about $20 \%$ of patients were diagnosed with $\mathrm{FH}$ by means of the screening program. Moreover, the lipid screening program allowed for the diagnosis of $\mathrm{FH}$ not only in the children included in the screening, but also their asymptomatic parents and siblings, as is the case in the biotinidase deficiency screening program (16). These findings show that screening for common diseases in the community is effective for the diagnosis of asymptomatic patients and the initiation of appropriate treatment.

The family history of patients plays a key role in the diagnosis of dyslipidemia, especially $\mathrm{FH}$, which is inherited in an autosomal codominant pattern (17). Another notable finding of the present study is that the history of dyslipidemia and its treatment with lipid-lowering drugs in parents were significantly higher in those patients diagnosed with $\mathrm{FH}$ compared to the other groups. This result highlights the importance of being aware of the family history of the patients enrolled in lipid screening.

In this study, we had no information about the number of children screened for dyslipidemia by family physicians, which prevented us from evaluating the frequency of dyslipidemia in school-aged children. Previous studies from different countries have diverse results. For instance, a study performed in Lebanon revealed high borderline dyslipidemia prevalence to be $77.3 \%$ in children 2-10 years old, while a Mexican study stated that the frequency of dyslipidemia in the same age group was $55.3 \%(18,19)$. A lower prevalence of dyslipidemia was reported from the USA at $8 \%$ for TC, $7 \%$ for LDL-C and $12 \%$ for triglyceride (20). We think that genetic variation and dietary habits play a key role in these differences. Furthermore, different rates of prevalence between countries suggest that every screening program should be revised in terms of national risk factors and screening age.

Previous studies about dyslipidemia screening in children did not determine hypobetalipoproteinemia (18-21). One of the striking finding of our study is that we revealed 4 children with hypobetalipoproteinemia. Although patients with hypobetalipoproteinemia are often asymptomatic, many develop fatty liver. In 2 out of the 4 patients with hypobetalipoproteinemia, we detected hepatomegaly, and hepatosteatosis. Two of them were asymptomatic. This finding emphasized that a screening program is effective in the detection of not only $\mathrm{FH}$ but also other types of dyslipidemias such as hypobetalipoproteinemia, or hyperchylomicronemia.

A study performed by Kalkan-Ucar et al. (22) in the same region as our study determined that the prevalence of obesity is $6.29 \%$ in children aged 2-15 years. However, this study was performed in 2009 and included children less than 5 years of age. It is well known that the number of obese children has significantly increased in developed and developing countries over the last decades (23). A recent study performed in Antalya located in southern Turkey reported that the prevalence of obesity was $9.8 \%$ in children aged 9-14 years in 2015 (24). The lipid profile screening program has provided an opportunity to determine the prevalence of obesity in children with abnormal lipid profile. We found the frequency of obesity to be $15 \%$, which was higher than that estimated in previous studies. This study is the first in our country to evaluate the frequency of obesity in school-age children diagnosed with dyslipidemia.

There are several limitations of this study. First, we had no information about the number of children screened for dyslipidemia, which prevented us from evaluating the frequency of dyslipidemia in school-aged children. Secondly, this study relied only on the lipid screening results of one centre located in the western region of Turkey. Lastly, the low-number of subgroups limited our ability to analyse the effectivity of laboratory parameters in the diagnosis of dyslipidemia.

\section{Conclusion}

Screening programs are effective in diagnosing not only the patients but also their asymptomatic parents and siblings. Evaluation and verification of dyslipidemia should be performed in a fasting state to avoid false positive results. Analysis of multicentre screening results is warranted to further analyse the effectiveness of lipid profile screening programs in school-age children.

\section{Ethics}

Ethics Committee Approval: The study protocol was designed in compliance with the 1964 Declaration of Helsinki. The study was approved by the Ethics Committee of University of Health Sciences Turkey, Dr. Behçet Uz Children Training and Research Hospital (date: 12.09.2019, number: 2019/326).

Informed Consent: Informed consent was obtained from the parents of participants.

Peer-review: Internally and externally peer-reviewed.

\section{Authorship Contributions}

Concept: E.K., M.K., B.Ö., Design: E.K., M.K., Data Collection or Processing: E.K., S.T., B.M., B.B., Analysis or Interpretation: E.K., Literature Search: E.K., Writing: E.K. 
Conflict of Interest: No conflict of interest was declared by the authors.

Financial Disclosure: The authors declared that this study received no financial support.

\section{References}

1. Ergin $A$, Muntner $P$, Sherwin $R, H e$ J. Secular trends in cardiovascular disease mortality, incidence, and case fatality rates in adults in the United States. Am J Med 2004; 117:219-27.

2. National Institutes of Health National Heart, Lung, and Blood Institute. Expert panel on integrated pediatric guideline for cardiovascular health and risk reduction in children and adolescents: summary report. Pediatrics 2011; 128:1-44.

3. Bibbins-Domingo K, Grossman DC, Curry S), et al. Screening for lipid disorders in children and Adolescents: US preventive services task force recommendation statement. JAMA 2016; 316:625-33.

4. Committee on Practice, Ambulatory Medicine, Bright Futures Steering Committee. Recommendations for preventive pediatric health care. Pediatrics 2007; 120:1376.

5. Ritchie SK, Murphy EC, Ice C, et al. Universal versus targeted blood cholesterol screening among youth: The CARDIAC project. Pediatrics 2010; 126:260-5.

6. Okul_sağlığının_korunması_ve_gelyytyrlmesy_programı uygulama_kılavüu. Last Accessed Date: 01.07.2020. Available from: https://okulsagligi.meb.gov.tr/meb iys dosyalar/2017 03/24172657 OKUL SAYLIYININ KOR̄UNMASI VE GELȲYTYRLMESY PRO'OGRAMI UYGULAMA KILAVUZU 325 $\overline{5} 68 \overline{3} 6380940747639 . \bar{p} \mathrm{df}$.

7. Ogden $\mathrm{CL}$, Flegal KM. Changes in terminology for childhood overweight and obesity. Natl Health Stat Report 2010; 25:1-5.

8. Expert Panel on Integrated Guidelines for Cardiovascular Health and Risk Reduction in Children and Adolescents, National Heart, Lung, and Blood Institute. Expert panel on integrated guidelines for cardiovascular health and risk reduction in children and adolescents: summary report. Pediatrics 2011; 128:213-56.

9. Welty FK. Hypobetalipoproteinemia and abetalipoproteinemia. Curr Opin Lipidol 2014; 25:161-8.

10. Nordestgaard BG, Langsted A, Mora S, et al. Fasting is not routinely required for determination of a lipid profile: clinical and laboratory implications including flagging at desirable concentration cutpoints-a joint consensus statement from the European Atherosclerosis Society and European Federation of Clinical Chemistry and Laboratory Medicine. Clin Chem 2016; 62:930-46.

11. Szternel L, Krintus M, Bergmann K, Derezinski T, Sypniewska G. Non-fasting lipid profile determination in presumably healthy children: Impact on the assessment of lipid abnormalities. PLoS One 2018; 13:e0198433. doi: 10.1371/journal.pone.0198433.
12. Langsted A, Freiberg IJ, Nordestgaard BG. Fasting and nonfasting lipid levels: influence of normal food intake on lipids, lipoproteins, apolipoproteins, and cardiovascular risk prediction. Circulation 2008; 118:2047-56.

13. Langsted A, Nordestgaard BG. Nonfasting lipids, lipoproteins, and apolipoproteins in individuals with and without diabetes: 58434 individuals from the Copenhagen General Population Study. Clin Chem 2011; 57:482-9.

14. Özbek İpteç B, Balik AR, Yüksel S, Yilmaz FM, Yilmaz G. Hemodilution is not the only reason of difference: Comparison of fasting and non-fasting lipoproteins in paired samples. Clin Biochem 2018; 61:28-33.

15. Mozaffarian D, Benjamin E), Go AS, et al; American Heart Association Statistics Committee and stroke statistics subcommittee. Heart disease and stroke statistics-2015 update: a report from the American Heart Association. Circulation 2015; 131:e29-322. doi: 10.1161/CIR.0000000000000152.

16. Canda $E$, Yazici $H, E r E$, et al. Single center experience of biotinidase deficiency: 259 patients and six novel mutations. Pediatr Endocrinol Metab 2018; 31:917-26.

17. Langslet G, Ose L. Screening methods in the diagnosis and assessment of children and adolescents with familial hypercholesterolemia. Expert Rev Cardiovasc Ther 2013; 11:10616.

18. Georges N, Simon A, Naim B, Georges N, Georges AF, Tanios A. Universal screening program for lipid disorders in 2-10 years old Lebanese children: A new approach. Int I Pediatr Adolesc Med $2019 ; 6: 101-8$.

19. Bibiloni Mdel M, Salas R, Novelo HI, Villarreal IZ, Sureda A, Tur IA. Serum lipid levels and dyslipidaemia prevalence among 2-10 year-old Northern Mexican children. PLoS One 2015; 10:e0119877. doi: 10.1371/journal.pone.0119877.

20. De Ferranti S, Jane N. Dyslipidemia in children: definition, screening, and diagnosis. UpToDate; 2020. Last Accessed Date: 01.07.2020. Available from: https://www-uptodatecom.ezproxy.usek.edu.lb/contents/dyslipidemia-inchildren-definition-screening-anddiagnosis?source.search result\&search.dyslipidemia in children\&selectedTitle.1 150.

21. Smith AJ, Turner EL, Kinra S. Universal Cholesterol Screening in Childhood: A Systematic Review. Acad Pediatr. 2016; 16:716-25.

22. Kalkan-Ucar S, Dizdarer C, Darcan S, et al. Prevalence of obesity and overweight among children in Izmir, Turkey: effects of nutritional and socio-economic factors. Obes Metab 2009; 5:99-106.

23. Wang Y, Lobstein T. Worldwide trends in childhood overweight and obesity. Int J Pediatr Obes 2006; 1:11-25.

24. Çelmeli G, Çürek Y, Arslan Gülten Z, et al. Remarkable increase in the prevalence of overweight and obesity among school age children in Antalya, Turkey, between 2003 and 2015. I Clin Res Pediatr Endocrinol 2019; 11:76-81. 